\title{
PENGEMBANGAN KETRAMPILAN BERPIKIR TINGKAT TINGGI DENGAN MENGGUNAKAN STRATEGI METAKOGNITIF MODEL PEMBELAJARAN PROBLEM BASED LEARNING
}

\author{
Sucipto \\ FKIP Universitas Dr. Soetomo \\ E-mail: kangsucipto@yahoo.co.id
}

\begin{abstract}
Abstrak
Laporan PISA dan TIMSS menunjukkan peserta Indonesia hanya mampu mencapai tingkatan kedua dari enam tingkatan berpikir pada soal yang dikompetisikan. Ini menunjukkan bahwa kemampuan peserta didik dalam berpikir logis dan rasional masih rendah dibanding negara lain. Untuk mengembangkan ketrampilan berpikir tingkat tinggi, pendidik dituntut kreatif untuk menciptakan suasana belajar dan menggunakan berbagai strategi pembelajaran yang mendukungnya. Strategi metakognitif problem solving dan problem based learning (PBL) merupakan alternatif strategi pembelajaran yang perlu dipertimbangkan. Berdasarkan beberapa kajian empiris membuktikan bahwa penggunaan strategi metakognitif problem solving dan problem based learning mampu mengembangkan ketrampilan berpikir tingkat tinggi peserta didik.
\end{abstract}

Kata Kunci: ketrampilan berpikir tingkat tinggi, strategi metakognitif problem solving, problem based learning

\section{Abstract}

The PISA and TIMSS reports show that Indonesian participants are only able to reach the second level of the six levels of thinking on the matter being competed. This shows that the ability of learners in logical and rational thinking is still low compared to other countries. To develop high-level thinking skills, educators are required to creatively create an atmosphere of learning and use the various learning strategies that support it. Metacognitive problem solving and problem based learning (PBL) strategies are an alternative learning strategy that needs to be considered. Based on several empirical studies proving that the use of metacognitive strategies of problem solving and problem-based learning can develop high-order thinking skills of learners.

Keywords: high-order thinking skills, metacognitive problem solving strategies, problem based learning learning

\section{PENDAHULUAN}

Era globalisasi ditandai dengan persaingan antar negara dalam berbagai aspek kehidupan termasuk sumber daya manusia. Kualitas sumber daya manusia bukan saja akan menentukan kemajuan suatu negara tetapi juga menjadi penentu daya saing antar bangsa. Kondisi demikian mendorong bidang pendidikan untuk terus berbenah untuk menghasilkan sumber daya manusia yang berkualitas. Pendidikan harus didesain untuk mampu membekali peserta didik yang tanggap terhadap tantangan era globalisasi. Untuk menghadapi tantangan tersebut, maka perlu melatih peserta didik agar mampu belajar secara mandiri dan berkembang kemampuan bernalar serta berpikirnya. Hal ini sejalan dengan tujuan pembelajaran dari sekolah dasar sampai perguruan tinggi adalahyaitu membentuk manusia intelektual, mampu memecahkan permasalahan serta mampu berpikir/bernalar (Atmadi dan Setyaningsih, 2000).

Secara umum capaian ketrampilan berpikir peserta didik Indonesia hingga saat ini masih kalah dibandingkan negara lain. Laporan PISA (Program for International Student Assessment) dan TIMSS (Trends in International
Mathematics and Science Study) menunjukkan bahwa peserta Indonesia hanya mampu mencapai tingkatan kedua dari enam tingkatan berpikir pada soal yang dikompetisikan. Ini menunjukkan bahwa kemampuan peserta didik dalam berpikir logis dan rasional masih rendah, sehingga ranking capaian dari tahun ke tahun masih pada level rendah diantara negara peserta (Sani, 2016).

Untuk meningkatkan ketrampilan berpikir peserta didik, pendidik dituntut kreatif untuk menciptakan suasana belajar yang mendukung dan menggunakan berbagai strategi pembelajaran serta sejumlah faktor yang dapat memfasilitasi peserta didik. Strategi pembelajaran yang ideal untuk menumbuhkembangkan keterampilan berpikir tingkat tinggi adalah stategi yang berpusat pada peserta didik (student centered learning). Pembelajaran ini memungkinkan peserta didik untuk mengekspresikan gagasannya secara terbuka, dan mengembangkan ketrampilan berpikir. Limbac \& Waugh (2011) menegaskan bahwa keberhasilan pelaksanaan proses pengembangan keterampilan berpikir tingkat tinggi saat ini membutuhkan pertimbangan bijaksana teknik instruksional dan komitmen untuk 
lingkungan aktif yang berpusat pada peserta didik. Pendapat serupa juga dikemukakan Knapp \& Glenn (1996), ketrampilan berpikir tingkat tinggi hanya dapat dikembangkan jika peserta didik diberi kesempatan untuk secara aktif merekayasa dan mensintesis informasi sedemikian rupa sehingga dapat melengkapi dan memperluas pemahaman yang sudah ada.

Seiring perkembangan psikologi kognitif, maka cara pendidik dalam mengevaluasi pencapaian hasil belajar, terutama untuk domain kognitif juga mengalami perubahan. Taksonomi Bloom yang direvisi Lorin W. Anderson (Anderson \& Krathwohl, 2001) telah memisahkan antara dimensi pengetahuan (knowledge) dan dimensi proses kognitif (cognitive processes). Pemisahan ini bukan hanya memperjelas kedudukan kedua dimensi tersebut namun juga memperluas cakupan kedua dimensi.

Upaya meningkatkan ketrampilan berpikir peserta didik dapat dilakukan dengan meningkatkan ketrampilan metakognisinya. Ketrampilan metakognitif diperlukan untuk kesuksesan belajar, mengingat ketrampilan metakognitif memungkinkan peserta didik mampu mengelola kecakapan kognitif dan mampu melihat kelemahannya sehingga dapat dilakukan perbaikan pada tindakan berikutnya. Lebih lanjut, dinyatakan bahwa peserta didik yang menggunakan keterampilan metakognitifnya memiliki prestasi yang lebih baik dibandingkan yang tidak menggunakan keterampilan metakognitifnya. Dengan ketrampilan metakognitif memungkinkan peserta didik untuk melakukan perencanaan, mengikuti perkembangan, dan memantau proses belajarnya (Susan, 2002). Sedang strategi metakognisi (Flavell, 1981), merujuk kepada cara untuk meningkatkan kesadaran mengenai proses berpikir dan pembelajaran yang berlaku. Sehingga apabila kesadaran ini terwujud, maka seseorang dapat mengawal pikirannya dengan merancang, memantau (memonitor) dan menilai apa yang dipelajarinya (mengevaluasi).

Boekaerts \& Simons (1995:91) mengidentifikasi berbagai strategi metakognitif yang dapat diterapkan dalam proses pembelajaran, satu diantaranya dengan kegiatan pemecahan masalah (problem solving). Dalam pemecahan masalah, pengetahuan yang ada diterapkan untuk situasi yang baru untuk memperoleh pengetahuan baru (Killen dalam Kotze, 2009). Kegiatan pemecahan masalah merupakan cara ideal untuk meningkatkan strategi metakognitif, sebagai pemecah masalah yang baik, pemikir umumnya sadar diri. Peserta didik dengan kemampuan metakognitif superior adalah pemecah masalah yang lebih baik. Kemampuan untuk menganalisis strategi pemecahan masalah dan merefleksikan pemikirannya mencerminkan keterampilan metakognitif peserta didik (Blakey \& Spence, 1990:2).

Penelitian yang dilakukan Yustina, dkk. (2015) menemukan bahwa kemampuan berpikir kritis siswa yang belajar menggunakan metode pembelajaran problem solving lebih baik dibanding dengan siswa yang belajar menggunakan pembelajaran konvensional. Hal tersebut sejalan dengan pendapat Kardi dan Nur (2000:16) yang menyatakan bahwa model pembelajaran problem solving sangat efektif untuk mengajarkan proses-proses berpikir tingkat tinggi, membantu siswa memproses informasi yang telah dimilikinya, dan membantu siswa membangun sendiri pengetahuannya tentang dunia sosial dan fisik disekelilingnya. Selain problem solving, model problem based learning mempunyai keunggulan dalam mengembangkan ketrampilan berpikir tingkat tinggi peserta didik. Berdasarkan kajian empiris yang dilakukan Mayasari (2015); Noma, dkk (2016); Fatchiyah (2016); menyimpulkan bahwa penerapan model PBL dapat meningkatkan keterampilan berpikir tingkat tinggi siswa secara signifikan. Lebih lanjut penelitian Prasetyani, dkk (2016) mengidentifikasi bahwa indikator kemampuan menganalisis memiliki persentase kemunculan tertinggi kemudian diikuti kemampuan mengevaluasi dan kemunculan terendah adalah mengkreasi.

Berdasarkan paparan tersebut, pertanyaan yang akan dibahas adalah bagaimana strategi metakognitif problem solving dan model pembelajaran PBL dalam mengembangkan ketrampilan berpikir tingkat tinggi peserta didik?

\section{PEMBAHASAN}

\section{Ketrampilan Berpikir Tingkat Tinggi}

Berpikir merupakan aktivitas mental yang terjadi apabila seseorang menghadapi masalah atau situasi yang harus dipecahkan. Kegiatan berpikir dapat diklasifikasikan menjadi berpikir tingkat rendah (lower order thinking) dan berpikir tingkat tinggi (higher order thinking). Menurut Heong, et. al (2011) kemampuan berpikir tingkat tinggi didefinisikan sebagai penggunaan pikiran secara luas untuk menemukan tantangan baru. Kemampuan berpikir tingkat tinggi ini menghendaki seseorang untuk menerapkan informasi baru atau pengetahuan sebelumnya dan memanipulasi informasi untuk menjangkau kemungkinan jawaban dalam situasi yang baru. Woolfolk (2008), menyatakan peserta didik yang memiliki keterampilan berfikir tingkat tinggi mampu membedakan antara fakta dan opini, mengidentifikasi informasi yang relevan, memecahkan masalah, dan mampu menyimpulkan informasi yang telah dianalisisnya.

Proses berpikir tingkat tinggi terkait dengan tiga asumsi tentang pemikiran dan pembelajaran. Pertama, tingkat pemikiran tidak dapat dilepaskan dari tingkat pembelajaran bahkan saling tergantung. Kedua, berpikir terkait dengan konten materi pelajaran dalam kehidupan nyata yang akan membantu mempelajari keterampilan berpikir tingkat tinggi. Ketiga, pemikiran tingkat tinggi melibatkan berbagai proses berpikir yang diterapkan pada situasi yang kompleks dan memiliki banyak variabel (King, et. al. - ).

Berdasarkan taksonomi Bloom, ketrampilan berpikir tingkat tinggi adalah kegiatan berpikir yang melibatkan level kognitif hirarki tinggi. Secara hirarki taksonomi Bloom terdiri dari enam level, yaitu pengetahuan (knowledge), pemahaman (comprehension), pengaplikasian (application), analisis (analysis), sintesis (synthesis), dan evaluasi (evaluation). Anderson \& Krathwohl (2001) mengembangkan taksonomi Bloom menjadi mengingat (remember), memahami 
(understand), mengaplikasikan (apply), menganalisis (analyze), mengevaluasi (evaluate) dan menciptakan (create). Dalam perkembangannya remembering, understanding, applying dikategorikan dalam recalling dan processing, sedangkan analysing dan evaluating dikategorikan dalam critical thinking dan yang terakhir creating dikategorikan dalam creative thinking. Thomas, Thorne \& Small (dalam Aprianti, 2013) menyimpulkan bahwa berpikir tingkat tinggi merupakan gabungan dari berpikir kritis, berpikir kreatif, dan berpikir pengetahuan dasar.

Berpikir tingkat tinggi pada taksonomi Bloom (edisi 2001) dimulai dengan proses kognitif: menganalisis, mengevaluasi hingga menciptakan sesuatu. Pada setiap tingkatan proses kognitif tersebut subjek didik membutuhkan pengetahuan metakognitif, mulai dari pengetahuan strategik, pengetahuan tentang tugas kognitif, dan pengetahuan tentang diri sendiri. Menganalisis merupakan proses memecah suatu materi menjadi bagian-bagian dan mendeteksi bagaimana bagian-bagian tersebut terkait satu sama lain dan terkait pada keseluruhan struktur atau tujuan. Proses menganalisis ini melibatkan aktivitas membedakan (differentiating), mengorganisasikan (organizing), dan menghubungkan (attributing).

Mengevaluasi merupakan proses membuat penilaian berdasarkan pada kriteria dan standar tertentu. Proses ini melibatkan aktivitas mengecek (checking) dan mengkritisi (critiquing). Menciptakan merupakan proses menggabungkan elemen-elemen untuk membentuk suatu keseluruhan yang baru dan bertalian secara logis atau membuat sebuah produk yang original. Proses ini melibatkan aktivitas menghasilkan (generating), merencanakan (planning), dan memproduksi (producing) (Hanoum, 2014).

Keenam proses kognitif tersebut bersifat hirarkis dan saling berkaitan. Semakin tinggi tingkatan proses berpikir semakin tinggi pula keterampilan berpikir yang dibutuhkan. Dengan demikian untuk dapat menganalisis, mengevaluasi dan menciptakan dengan baik, maka peserta didik diharuskan untuk dapat mengingat, memahami dan mengaplikasikan dengan baik terlebih dahulu.

Resnick dalam Nur (2011) mengidentifikasi ciriciri berpikir tingkat tinggi sebagai berikut: (1) berpikir tingkat tinggi bersifat non algoritmik. Artinya, urutan tindakan itu tidak dapat sepenuhnya ditetapkan terlebih dahulu, (2) berpikir tingkat tinggi cenderung kompleks. Urutan atau langkah-langkah keseluruhan itu tidak dapat "dilihat" hanya dari satu sisi pandangan tertentu, (3) berpikir tingkat tinggi sering menghasilkan multi solusi, setiap solusi memiliki kekurangan dan kelebihan, (4) berpikir tingkat tinggi melibatkan perti mbangan yang seksama dan interpretasi, (5) berpikir tingkat tinggi melibatkan penerapan multi kriteria sehingga kadangkadang terjadi konflik kriteria yang satu dengan yang lain, (6) berpikir tingkat tinggi sering melibatkan ketidakpastian. Tidak semua hal yang berhubungan dengan tugas yang sedang ditangani dapat dipahami sepenuhnya, (7) berpikir tingkat tinggi melibatkan pengaturan diri dalam proses berpikir. Seorang individu tidak dapat dipandang berpikir tingkat tinggi apabila ada orang lain yang membantu di setiap tahap, (8) berpikir tingkat tinggi melibatkan penggalian makna, dan penemuan pola dalam ketidakteraturan, (9) berpikir tingkat tinggi merupakan upaya sekuat tenaga dan kerja keras.

Berfikir tingkat tinggi melibatkan kerja mental besar-besaran yang diperlukan dalam elaborasi dan pemberian pertimbangan. Sementara Sudiarta (2006) menjelaskan keterkaitan berpikir tingkat tinggi dengan hal-hal sebagai berikut: (1) kemampuan menyelesaikan masalah-masalah baru yang non-rutin dan tak terduga, (2) kemampuan melakukan aktivitas-aktivitas analisis, sintesis, evaluasi secara sistematis, (c) kemampuan melakukan berbagai prediksi yang bermanfaat terhadap fenomena alam dan kehidupan secara orisinil, kritis, dan kreatif.

Limbach \& Wendy (2009), mengidentifikasi lima langkah proses pengembangan ketrampilan berpikir tingkat tinggi yang dapat diimplementasikan hampir semua lingkungan pembelajaran peserta didik aktif. Lima langkah tersebut adalah: (1) menetapkan rumusan pembelajaran yang mempercepat peserta didik ke tingkat yang lebih tinggi, (2) mengajukan pertanyaan. Tingkat pemikiran siswa berbanding lurus dengan tingkat pertanyaan yang diajukan, (3) praktik sebelum penilaian. Memilih kegiatan belajar yang memungkinkan peserta didik untuk berlatih akan mendorong mereka berpikir kritis, (4) melakukan review, menyaring, dan memperbaiki pembelajaran, dan (5) memberikan umpan balik dan penilaian pembelajaran

\section{Strategi Metakognitif Problem Solving}

Strategi Metakognitif

Metakognitif i adalah istilah yang diperkenalkan Flavell pada tahun 1976. Kuhn (2000) mendefinisikan metakognisi sebagai kesadaran dan menajemen dari proses dan produk kognitif yang dimiliki seseorang, atau secara sederhana disebut sebagai "berpikir mengenai berpikir". Demikian juga Wellman (1985) menyatakan bahwa metakognisi adalah suatu bentuk kognisi, proses berpikir urutan kedua atau lebih tinggi yang melibatkan kontrol aktif atas proses kognitif. Metakognisi juga didefinisikan sebagai "berpikir tentang berpikir" atau "kognisi seseorang tentang kognisi". Metakognitif sebagai suatu bentuk kognisi, atau proses imunisasi meliputi tingkat berpikir yang lebih tinggi, melibatkan pengendalian terhadap aktivitas kognitif.

Metakognitif adalah suatu pengetahuan (knowledge) mengenai proses berpikir yang lebih tinggi dengan melibatkan kontrol, pengendalian atau pengaturan (regulation) aktif dalam belajar. Hal ini menunjukkan bahwa pengetahuan-kognisi adalah kesadaran seseorang tentang apa yang sesungguhnya diketahuinya dalam belajar dan regulasi-kognisi adalah bagaimana seseorang mengatur aktivitas kognitifnya secara efektif dalam belajar. Karena itu, pengetahuan-kognisi memuat pengetahuan deklaratif, prosedural, dan kondisional, sedang regulasi-kognisi mencakup kegiatan perencanaan, 
prediksi, monitoring (pemantauan), pengujian, perbaikan (revisi), pengecekan (pemeriksaan), dan evaluasi.

Berdasarkan beberapa pengertian di atas disimpulkan bahwa metakognitif adalah suatu kesadaran tentang kognitif kita sendiri, bagaimana kognitif kita bekerja serta bagaimana mengaturnya. Kemampuan ini sangat penting terutama untuk keperluan efisiensi penggunaan kognitif kita dalam menyelesaikan masalah. Secara ringkas metakognitif dapat diistilahkan sebagai "thinking about thingking".

Strategi metakognitif mengacu pada peningkatan kesadaran seseorang untuk mencapai tujuan (belajar) tertentu. Apabila kesadaran ini terwujud, maka seseorang dapat mengawal pikirannya dengan merancang, memantau (memonitor) dan menilai apa yang dipelajarinya (mengevaluasi). Hal ini seperti dikemukakan Flavell (1981:273), " Metacognitive strategies refer to the conscious monitoring of one's cognitive strategies to achieve specific goals, for example when learners ask themselves questions about the work and then observe how well they answer these questions". Sementara Boekaerts and Simons (1995: 91) "view metacognitive strategies as the decisions learners make before, during and after the process of learning".

Strategi metakognitif dalam proses pembelajaran cukup bervariasi. Bebeberapa faktor yang menjadi pertimbangan dalam pemilihan strategi metakognitif diantaranya: karakteristik siswa, karakteristik bidang kajian, dan karakteristik pembelajaran. Boekaerts \& Simons (1995: 91) mengidentifikasi berbagai strategi metakognitif dalam proses pembelajaran sebagai berikut: (1) strategi perencanaan, (2) membangkitkan pertanyaan, (3) memilih secara sadar, (4) menetapkan tujuan, (5) mengevaluasi cara berpikir dan bertindak, (6) mengidentifikasi kesulitan, (7) parafrase, mengelaborasi dan menggali ide-ide peserta didik, (8) mengklarifikasi terminologi peserta didik, (9) kegiatan pemecahan masalah, (10) berpikir keras, (11) jurnal-keeping, (12) pembelajaran kooperatif, dan (13) pemodelan.

\section{Kegiatan Pemecahan Masalah (Problem Solving)}

Problem solving merupakan salah satu strategi metakognitif yang dapat digunakan dalam pembelajaran. Sudjana (2005:125) menyatakan bahwa strategi problem solving adalah suata teknik yang menggambarkan pengalaman atau masalah seseorang yang disusun untuk memancing perhatian atau perasaan para peserta didik. Pemecahan masalah dapat dipergunakan untuk menggerakkan diskusi, meningkatkan kemampuan peserta didik, menganalisis, menilai, dan memecahkan masalah yang dihadapi dalam dunia kehidupannya. Pemecahan masalah kritis dapat dipergunakan pula sebagai aktivitas belajar perorangan, kelompok dan kombinasi keduanya. Lebih lanjut Sudjana (2012) mengidentifikasi lima langkah yang dapat dilakukan dalam menggunakan strategi problem solving, yaitu (1) pendidik dan peserta didik menyusun permasalahan sebagai bahan belajar, (2) pendidik menjelaskan kegiatan yang akan dilakukan oleh peserta didik, (3) peserta didik baik secara individu/kelompok mendapat sebuah bahan pemecahan masalah yang sama, (4) pada ahir kegiatan belajar pendidik/peserta ditunjuk menyimpulkan dan (5) pendidik dan peserta didik melakukan evaluasi proses dan hasil.

Ada dua teknik yang dapat digunakan oleh guru dalam problem solving, yaitu mengajarkan aspek-aspek pemecahan masalah dan mengubah peranan guru menjadi fasilitator, pelatih, dan motivator (Lew dalam Sudjimat, 1996). Selanjutnya dikatakan ada tiga aspek yang berguna bagi siswa yaitu: (1) proses mental, (2) strategi pemecahan masalah dan (3) latihan dan pemberian umpan balik. Ketiga aspek tesebut berkaitan dengan pendapat Depoter dan Hemacki (dalam Hafid, 2007) bahwa keberhasilan seseorang memecah masalah dapat dilihat dan kemampuan mengombinasikan antara pikiran yang logis dan kemampuan kreativitas.

Masalah terjadi ketika ada kesenjangan antara keadaan dan tujuan yang diinginkan. Pemecahan masalah diperlukan pada berbagai aspek kehidupan dalam realitas atau permainan. Hal ini juga dianggap sebagai paradigma kognisi rumit yang tak terpisahkan dari praktik kehidupan sehari-hari (Gok, 2010). Pemecahan masalah tidak hanya ada pada bidang matematika, tetapi mencakup banyak peristiwa yang terjadi dalam pengalaman kehidupan nyata.

Pemecahan masalah dapat diidentifikasi sebagai "pengetahuan dan proses" yang bisa mengarahkan dan membimbing proses berpikir individu ke arah mencapai solusi yang baik. Suatu model mental yang efisien yang memungkinkan bagi pemecah masalah untuk mengatur dan merangkai informasi, mengontrol strategi solusi, dan membantu dalam generalisasi (Mayer, 1998). Seberapa jauh efisien pemecahan masalah bergantung pada "sifat dan organisasi" dari pengetahuan yang dimilikinya, itulah sebabnya mengapa siswa yang memiliki kemampuan lebih baik akan lebih berpeluang untuk menjadi siswa yang lebih baik (Bransford et. al, 1986).

Dalam proses pemecahan masalah, individu menggunakan kedua kemampuan kognitif dan keterampilan praktis, yang meliputi kegiatan metakognitif seperti analisis, sintesis, evaluasi atau kreasi. Pemecahan masalah membutuhkan tiga syarat utama, yaitu: memikirkan masalah dan tindakan mencapai tujuan, mencari strategi yang dapat membantu dalam mencapai tujuan, dan akhirnya melaksanakan strategi dalam bentuk tindakan (Kafadar dalam Aljaberi, 2015). Sementara Sujimat (1996:27) menyatakan bahwa ada tiga elemen dalam pemecahan masalah, yaitu (1) representasi masalah (2) prosedur pemecahan masalah (3) pengenalan masalah.

Kemampuan memecahkan masalah sangat berpengaruh bagi kemampuan berpikir seseorang. Hal ini sebagaimana yang dinyatakan oleh Wikefiel (1992) bahwa salah satu kemampuan berpikir peserta didik yang berkaitan dengan pemecahan masalah dan strategi pemecahannya adalah kemampuan berpikir kritis. 


\section{Metakognisi pada Problem Solving}

Metakognisi membahas tentang bagaimana menciptakan dan menganalisis pikiran dan ide-ide, dan pada dasarnya merupakan cara untuk menarik kesimpulan berdasarkan analisis, dan akhirnya bagaimana menerapkan apa yang telah didapatkan melalui pembelajaran praktis. Untuk mengatasi masalah, siswa wajib memahami jalan pikirannya bekerja dan berfungsi, serta bagaimana mereka melakukan tugastugas kognitif penting seperti mengingat, belajar dan pemecahan masalah (Noushad dalam Aljaberi, 2015).

Peserta didik mampu mendefinisikan masalah, memilih strategi solusi yang tepat, memantau seberapa efektif solusi strategi, dan semuanya dukungan keterampilan metakognitif (Vaidya, 1999). Pemecahan masalah apapun merupakan fenomena yang mengharuskan seseorang untuk menentukan strategi yang diperlukan dan membuat keputusan untuk mencari solusi, metakognisi dianggap sebagai kunci penting untuk keberhasilan dalam pemecahan masalah. O'Neil \& Schacter (1997) mengusulkan model untuk pemecahan masalah, yang meliputi atas empat elemen prinsip, yaitu: "pemahaman isi, strategi pemecahan masalah, metakognisi, dan motivasi". Strategi, pemahaman isi digunakan untuk pemecahan masalah pada domain spesifik, sementara metakognisi dan motivasi untuk domain independen konstruksi.

Para peneliti juga menunjukkan bahwa proses kontrol, sebagai proses metakognitif, adalah salah satu perilaku pemikiran metakognitif yang paling penting, yang sebagian besar mempengaruhi proses pengambilan keputusan dalam pemecahan masalah. Lebih lanjut ditegaskan bahwa tiga komponen pemikiran metakognitif yang mempengaruhi pemecahan masalah adalah deklaratif, prosedural dan pengetahuan bersyarat (Carlson $\&$ Bloom, 2005).

\section{Model Pembelajaran Problem Based Learning (PBL)}

Menurut Suherman (dalam Nurdin, 2016:222) model pembelajaran dimaksudkan sebagai pola interaksi antara siswa dengan guru di dalam kelas. Model pembelajaran menyangkut penggunaan strategi, pendekatan, metode, dan teknik pembelajaran dalam proses belajar mengajar. Abdul Majid (2013) menjelaskan bahwa salah satu model pembelajaran yang dapat diterapkan berdasarkan permasalahan serta mampu melibatkan peserta didik secara langsung dalam proses pembelajaran yaitu model pembelajaran problem based learning (PBL).

Model pembelajaran problem based learning (PBL) atau pembelajaran berbasis masalah (PBS) pertama kali dikembangkan Howar Barrows pada Ilmu Pendidikan Medis di Southern Illinois University School. Pada gilirannya kemudian meluas ke Ilmu Pengetahuan alam di Perguruan Tinggi hingga ke sekolah menengah (Nurdin, 2016). Arends (2007:41) menyatakan bahwa model pembelajaran berdasarkan masalah adalah pendekatan pembelajaran dimana siswa dihadapkan pada masalah autentik dan bermakna. Hal ini berfungsi sebagai landasan bagi pengembangan dan penyelidikan siswa, sehingga dapat menyusun pengetahuannya sendiri, menumbuhkembangkan keterampilan yang lebih tinggi dan inquiri, memandirikan siswa, dan meningkatkan kepercayaan diri sendiri.

Model pembelajaran PBL adalah sebuah model pembelajaran yang didasarkan pada prinsip bahwa masalah (problem) dapat digunakan sebagai titik awal untuk mendapatkan atau mengintegrasikan ilmu (knowledge) baru. Berdasarkan pandangan psikologi kognitif terhadap tiga prinsip pembelajaran yang berkaitan dengan PBL, yaitu: (1) belajar adalah proses konstruktif dan bukan penerimaan, (2) knowing about knowing (metakognitif), dan (3) faktor-faktor kontekstual dan sosial mempengaruhi pembelajaran (Nurdin, 2016:223).

Tampaknya menyajikan masalah di awal pembelajaran tidak sulit, karena kesempatan ini mengundang rasa ingin tahu siswa, inkuiri, keterlibatan dalam pembelajaran dan motivasi belajar (Tan, 2003: 17). Lebih lanjut Tan (2003) mengemukakan beberapa ciri utama yang perlu ada di dalam pembelajaran berbasis masalah diantaranya: (1) pembelajaran berpusat atau bermula dari masalah, (2) masalah yang dipecahkan merupakan masalah aktual dan mungkin akan dihadapi oleh siswa di masa depan, (3) pengetahuan yang diharapkan dicapai oleh siswa semasa proses pembelajaran disusun berdasarkan masalah, (4) para siswa bertanggung jawab terhadap proses pembelajaran mereka sendiri, (5) siswa akan aktif dalam proses pembelajaran berlangsung, (6) pengetahuan yang ada akan menguatkan konstruksi pengetahuan yang baru, (7) pengetahuan akan diperoleh dalam konteks yang bermakna, dan (8) siswa berpeluang untuk meningkatkan serta mengorganisasikan pengetahuan.

Ibrahim dan Nur (dalam Nurdin, 2016) menjelaskan langkah-langkah (sintaks) PBL sebagai berikut:

\begin{tabular}{|c|c|c|}
\hline Fase & Indikator & Aktivitas Guru \\
\hline ( & $\begin{array}{l}\text { Orientasi siswa } \\
\text { pada masalah }\end{array}$ & $\begin{array}{l}\text { Menjelaskan tujuan } \\
\text { pembelajaran, menjelaskan } \\
\text { logistik yang diperlukan, } \\
\text { dan memotivasi siswa } \\
\text { terlibat pada aktivitas } \\
\text { pemecahan masalah }\end{array}$ \\
\hline 2 & \begin{tabular}{l}
\multicolumn{3}{l}{ Mengorganisasi } \\
siswa $\quad$ untuk \\
belajar
\end{tabular} & $\begin{array}{lr}\text { Membantu siswa } \\
\text { mendefinisikan dan } \\
\text { mengorganisasikan tugas } \\
\text { belajaryang berhubungan } \\
\text { dengan masalah tersebut. }\end{array}$ \\
\hline 3 & $\begin{array}{l}\text { Membimbing } \\
\text { pengalaman } \\
\text { individual/kelom } \\
\text { pok }\end{array}$ & $\begin{array}{l}\text { Mendorong siswa untuk } \\
\text { mengumpulkan informasi } \\
\text { yang sesuai, melaksanakan } \\
\text { eksperimen untuk } \\
\text { mendapatkan penjelasan } \\
\text { dan pemecahan masalah. }\end{array}$ \\
\hline
\end{tabular}




\begin{tabular}{|c|c|c|}
\hline Fase & Indikator & Aktivitas Guru \\
\hline 4 & $\begin{array}{l}\text { Mengembangkan } \\
\text { dan menyajikan } \\
\text { hasil karya }\end{array}$ & $\begin{array}{l}\text { Membantu siswa dalam } \\
\text { merencanakan } \\
\text { menyiapkan karya yang } \\
\text { sesuai seperti laporan dan } \\
\text { membantu mereka untuk } \\
\text { berbagi tugas dengan } \\
\text { temannya. }\end{array}$ \\
\hline 5 & $\begin{array}{l}\text { Menganalisis dan } \\
\text { mengevaluasi } \\
\text { proses } \\
\text { pemecahan } \\
\text { masalah }\end{array}$ & $\begin{array}{lrr}\text { Membantu } & \text { siswa untuk } \\
\text { melakukan } & \text { refleksi atau } \\
\text { evaluasi } & \text { terhadap } \\
\text { penyelidikan mereka dan } \\
\text { proses yang mereka } \\
\text { gunakan. }\end{array}$ \\
\hline
\end{tabular}

Sumber: (Nurdin, 2016: 226)

Problem based learning menganut pandangan kontruktivisme dalam pembelajaran dan memberikan kesempatan siswa untuk mengembangkan kemampuan berpikir kritis dan evaluatif melalui analisis masalah nyata dalam kehidupan sehari-hari (Smith, 1995). Selanjutnya PBL juga akan meningkatkan kemampuan berpikir dan kemampuan belajar serta kemampuan kognitif lainnya pada siswa. Hmleo \& Silver (2004) mengemukakan bahwa PBL didesain untuk membantu peserta didik membangun dasar pengetahuan yang luas dan fleksibel, mengembangkan self-directed learning, dan membangun motivasi instrinsik dalam belajar. John R. Savery (2006) menyimpulkan bahwa PBL mendukung pengembangan kemampuan memecahkan masalah, kemampuan belajar mandiri, dan kerja sama tim serta mampu meningkatkan prestasi belajar siswa

\section{Pengembangan Ketrampilan Berpikir Tingkat Tinggi Melalui Problem Solving dan Model PBL}

Problem based learning dan problem

solving merupakan model pembelajaran kontekstual yang menganut paradigma konstruktivistik dengan memberikan kondisi belajar aktif kepada peserta didik. Paradigma kontruktivistik menekankan peran aktif siswa dalam membangun sendiri pengetahuan yang ada pada dirinya. Antara problem solving dan problem based learning merupakan strategi pembelajaran yang mempunyai unsur kesamaan dan perbedaan. Beberapa kesamaan keduanya adalah: (1) berbasis masalah atau pemecahan masalah, (2) peran guru adalah sama-sama sebagai pendidik dan fasilitator, (3) langkah pembelajaran sama-sama diawali dengan pemberian masalah dari guru.

Selanjutnya perbedaan antara keduanya terletak pada masalah yang dipecahkan atau diselesaikan. Pada problem solving masalah yang diberikan bukan masalah yang nyata sementara model PBL bercirikan penggunaan masalah kehidupan nyata (kontekstual) diselesaikan dengan tingkat berpikir lebih tinggi, termasuk bagaimana belajar (Abbas dalam Syamsurizal, 2011). Cara penyelesaiannyapun juga terdapat perbedaan, pada problem solving masalah dapat diselesaikan hanya dengan diskusi saja akan tetapi pada PBL dibutuhkan penelitian mengenai masalah tersebut, sehingga penyelesaian yang diberikanbenar-benar melalui proses yang panjang.

Dengan menerapkan problem solving memungkinkan pengetahuan dan ketrampilan metakognisi peserta didik dalam pembelajaran dapat ditumbuhkan pada setiap fase pemecahan masalah: pemahaman masalah (understanding the problem), merencanakan pemecahan (devising a plan), melaksanakan pemecahan sesuai rencana (carrying out the plan), dan menafsirkan (looking back).

Pembelajaran berbasis masalah secara langsung banyak menghasilkan kelebihan dan rekomendasi, Duch et. al. (2001) mengidentifikasi sebagai berikut: (1) berpikir kritis dan mampu untuk menganalisis dan memecahkan yang kompleks, masalah nyata, (2) mencari , mengevaluasi, dan menggunakan sumber daya yang tepat belajar, (3) bekerja secara kooperatif dalam tim dan kelompok-kelompok kecil, (4) mendemonstrasikan keterampilan komunikasi serbaguna dan efektif, baik lisan dan tertulis, (5) menggunakan pengetahuan dan keterampilan intelektual yang diperolehnya untuk memecahkan masalah selanjutnya.

Ibrahim dan Nur (dalam Nurdin, 2016) mengemukakan bahwa pembelajaran berbasis masalah merupakan salah satu pendekatan pembelajaran yang digunakan untuk merangsang berpikir tingkat tinggi siswa dalam situasi yang berorientasi pada masalah yang nyata, termasuk di dalamnya belajar bagaimana belajar. Tan (2013) menegaskan bahwa perkembangan kecerdasan dalam pemecahan masalah dan kompetensi untuk pemecahan masalah secara kreatif merupakan tujuan penting dari PBL. Hal ini membutuhkan guru untuk mengarahkan dalam banyak proses pemikiran baik kognitif dan metakognitif. Adapun proses yang menyangkut keterlibatan dari masalah meliputi: klarifikasi masalah, definisi masalah dan reframing, analisis masalah, ringkasan masalah dan sintesis.

Duch et. al. (2001) menegaskan bahwa pembelajaran dengan menggunakan PBL dapat meningkatkan kemampuan berpikir kritis dan analisis, memecahkan masalah yang kompleks ataupun masalah nyata dalam keseharian, bekerja sama dalam kelompok, dan menunjukkan keterampilan komunikasi yang efektif baik lisan maupun tulisan. Hal tersebut dikuatkan dengan hasil penelitian Yuan, et.al. (2009) yang menunjukkan bahwa pembelajaran dengan PBL mampu meningkatkan kemampuan critical thinking daripada pembelajaran dengan menggunakan literatur.

Jadi dengan menerapkan model pembelajaran problem based learning dan problem solving mengkondisikan peserta didik untuk mengembangkan kemampuan berpikir setahap demi setahap mulai dari mendefinisikan masalah, mencari data, menganalisis, kemudian menyuguhkan alternatif. Hal ini merangsang peserta didik untuk mengembangkan kemampuan berpikir analisis dan evaluasinya atau 
berpikir kritis, logis, reflektif, metakognitif, dan berpikir kreatif. Berpikir kritis adalah kegiatan berpikir yang dilakukan dengan mengoperasikan potensi intelektual untuk merumuskan masalah, memberikan argumen, dan melakukan evaluasi. Berdasarkan hasil penelitian Rokhman (2914), penerapan model pembelajaran problem based learning dan problem solving dapat digunakan sebagai alternatif dalam pembelajaran untuk meningkatkan kemampuan berpikir kritis.

\section{PENUTUP}

\section{Simpulan}

Strategi metakognitif problem solving dan model pembelajaran problem based learning dikembangkan mengacu paradigma konstruktivistik. Keduanya merupakan strategi pembelajaran berbasis masalah atau pemecahan masalah yang mengkondisikan peserta didik untuk mengembangkan kemampuan berpikir setahap demi setahap mulai dari mendefinisikan masalah, mencari data, menganalisis, kemudian menyuguhkan alternatif. Peserta didik dirangsang mengembangkan kemampuan berpikir secara kritis, logis, reflektif, metakognitif, dan berpikir kreatif. Dengan demikian penerapan kedua strategi tersebut mampu mengembangkan ketrampilan berpikir tingkat tinggi peserta didik.

\section{Saran}

Untuk mengembangkan ketrampilan berpikir tingkat tinggi terutama critical thinking pada peserta didik, pendidik perlu mengembangkan strategi metakognitif problem solving dan problem based learning (PBL) dengan perencanaan secara cermat.

\section{DAFTAR PUSTAKA}

Aljaberi, N. M. 2015. University Student's Level of Metacognitive Thinking and Their Ability to Solve Problems. American International Journal of Contemporary Research, vol, 5, No 3; Juni 2015.

Aprianti, Vika. 2013. Pengaruh Penerapan Model Cooperative Learning Tipe Think Pair Share (TPS) Terhadap Kemampuan Berpikir Kritis Siswa Pada Pembelajaran Ekonomi. UPI.repository.upi.edu.

Arrend, I. 2007. Learning To Teach Sevent Edition. New York: McGraw Hill Companies.

Anderson, Lorin W \& Krathwohl, David R. 2001. Learning, Teaching, and Assessing: A revision of Bloom's Taxonomy of Educational Objectives. Longman; NY.

Atmadi dan Setyaningsih. 2000. Transformasi Pendidikan. Yogyakarta : Universitas Sanata Darma.
Blakey, E., \& Spence, S. 1990. Developing metacognition. Eric Reproduction Services No. ED327218. Retrieved from HYPERLINK "http://www.eric.ed.gov/PDFS/ED327218.pdf" http://www.eric.ed.gov/PDFS/ED327218.pdf Boekaerts, M., \& Simons, P. R. (1995). Leren en instructie: Psychologie van de leerling en het leerproses. Assen: Van Gorcum.

Boekaerts, M., \& Simons, P. R. 1995. Leren en instructie: Psychologie van de leerling en het leerproses.Assen: Van Gorcum.

Bransford, J., Sherwood, R., Vye, N., \& Rieser, J. 1986. Teaching Thinking and Problem Solving: Researchfoundations. American Psychologist, 41 (10), 1078.

Carlson, M. P. \& Bloom, I. 2005. The Cyclic Nature of Problem Solving: An emergent Multidimensional Problem Solving framework. Educational Studies in Mathematics, 58(1), 4575 .

Duch, B. J. 2001. The Power of Problem Based Learning. Virginia: Stylus Publishing.

Fatchiyah. 2016. Pengaruh Pbl Terhadap Kemampuan Berpikir Tingkat Tinggi Siswa Kelas V Sd SeGugus $01 \quad$ Kretek. Jurnal Pendidikan Guru Sekolah Dasar Edisi 18 Tahun ke-5 2016).

Flavell, J. H. 1981. Monitoring social cognitive enterprises: Something else that may develop in the area of social cognition. In J. H. Flavell \& L. Ross (Eds.), Social cognitive development: Frontiers and possible futures (pp. 272-287). New York:: Cambridge University Press.

Gok, T. 2010. The General Assessment of Problem Solving Processes in Physics Educatioon. Gok, T. 2010.The General Assessment of Problem Solving Pr Eurasian Journal of Physics and Chemistry Education, , 2(2), 110-122.

Hafid, Abdul. 2007. Mengembangkan Kemampuan Berpikir Kritis Melalui Teknik Problem Solving. Jurnal Iktiyar, Vol. 5, No. 3, Issn 1412-8535, Hal 126-277.

Heong, Y. M. 2011. The Level of Marzano Higher Order Thinking Skills Among Technical Education Students. International Journal of Social and humanity, Vol. 1,No. 2, July 2011, 121-125.

Hmelo-Silver CE. 2004. Problem-based learning: what and how do students learn? Educational Psychology Review. 16:235-66.

Kardi, M., \& Nur, M. 2000. Pengantar pada Pengajaran dan Pengelolaan Kelas. Surabaya: Universitas Pres. 
King, FJ, Ludwika Goodson, Faranak Rohani. Higher Order Thinking Skills: Definition, Teaching Strategies, Assessment. A publication of the Educational Services Program.

Knapp, Linda Roehrig \& Glenn, Allen D. 1996. Restructuring Schools with Technology.Massachusettes: Ally \& Bacon.

Krathwohl, D. R. 2002. A revision of Bloom's Taxonomy: an overview - Theory Into Practise. The Ohio State University: College of Education.

Kotze, Gary, Stephan du Toit. 2009. Metacognitive Strategies in the Teaching and Learning of Mathematics. Faculty of Education, University of the Free State.

Kuhn, D. 2000. Theory of Mind, Metacognition and Reasoning: A life-span Perspective. In P. Mitchell \& K. J. Riggs (Eds.). Children's Reasoning and The Mind (pp. 301-326). Hove, UK: Psychology Press.

Limbach. B \& Waugh.W. 2009. Developing Higher Level Thinking. Journal of Instructional Pedagogies: Chadron State College.

Majid, Abdul. 2013. Strategi Pembelajaran. Bandung: Rosda Karya.

Mayasari, Ria, Rabiatul Adawiyah. 2015. Pengaruh Model Pembelajaran Berdasarkan Masalah Pada Pembelajaran Biologi Terhadap Hasil Belajar dan Keterampilan Berpikir Tingkat Tinggi Di Sma. Jurnal Pendidikan Biologi Indonesia, Volume 1 Nomor 3 2015, : 2442-3750, Hal. 255-262)

Mayer, R. 1998. Cognitive, Metacognitive, and Motivational Aspets of Problem Solving. Instructionalscience, 26 (1-2), 49-63.

Noma, Luciana Dewi, dkk. 2016. PBL Untuk Meningkatkan Kemampuan Berpikir Tingkat Tinggi Siswa Kelas X Sma. Jurnal Bioedukasi, Volume 9, Nomor 2, ISSN: 1693 265X, Agustus 2016 Hal. 62-66).

Nur, Muhammad. 2011. Model Pembelajaran Berbasis Masalah. Surabaya: Universitas Negeri Surabaya.

Nurdin, Syafrududdin, Adriatoni. 2016. Kurikulum dan Pembelajaran. Jakarta: PT RajaGrafindo Persada.

O'Neil, H.F., \& Schacter, J. 1997. Test Specifications for Problem Solving Assessment. Center for the Study of Evaluation, National Center for Research on Evaluation, Standards, and Student Testing. Graduate Schoolof Education \& Information Studies, University of California, Los Angeles.
Prasetyani, Etika, Yusuf Hartono, dan Ely Susanti. 2016. Kemampuan Berpikir Tingkat TinggiSiswa Kelas XI dalam Pembelajaran rigonometri Berbasis Masalah Di Sma Negeri 18 Palembang. Jurnal Gantang Pendidikan Matematika Fkip Umrah, Vol. 1 No. 1, Agustus 2016, P-Issn. 2503-0671, E-Issn. 2548-5547.

Rokhman, Ayla Yuli. 2014. Perbandingan Model Pembelajaran Problem Based Learning dan Problem solving Terhadap Kemampuan Berpikir Kritis Pada Materi Pelestarian Lingkungan Hidup Siswa XI IPS MAN 3 Malang. Skripsi, Jurusan Pendidikan Geografi FIS Universitas Negeri Malang.

Sani, R. A. 2016. Penilaian Autentik. Jakarta: Bumi Akasara.

Sanjaya, W. 2007. Strategi Pembelajaran. Jakarta, DKI Jakarta, Indonesia: Kencana Prenada Media Group.

Sudiarta, P. 2006. Pengembangan model pembelajaran berorientasi pemecahan masalah open-ended berbantuan LKM untuk meningkatkan pemahaman konsep dan hasil belajar mahasiswa matakuliah pengantar dasar Matematika.Jurnal Pendidikan dan Pengajaran UNDIKSHA 39 Nomor 2, April 2006. Singaraja: UNDIKSHA.

Sudjana. I.W. 2002. Pengaruh Jenis Pendekatan Pembelajaran dan Tingkat Kemampuan Berpikir Kreatif Terhadap Perolehan Belajar IPS pada Siswa Kelas VI SD 17 Dauh Puri Denpasar. Malang: PPS UM. Tesis Tidak Diterbitkan.

Sudjimat, D.A. 1996. Pembelajaran Pemecahan Masalah. Tinjauan Singkat Berdasar Teori Kognitif. Jurnal Pendidikan Himaniora dan Sains @ (1\&2). hlm. 24-32.

Smith, C. A. 1995. Features section: problem based learning. Biochemistry and Molecular Biology Education Journal. 23 (3), 149-152.

Susan, Imel. 2002. Metacognitive Skills for Adult Learnin. (online). HYPERLINK "http://www.ce-" (http://www.ce te.org/ acve/docs/tia00107.pdf. Diakses 3 September 2012.

Syamsurizal, Eka Sastrawati, Muhammad Rusdi. 2011. Problem Based Learning, Strategi Metakognisi, dan Berpikir Tingkat Tinggi Siswa. Univ. Jambi: Tekno-Pedagogi , vol. 1 No. 2 September 2011: 1- 14.

Tan, S. 2003. Problem Based Learning Innovation. Singapura: Cencage Learning. 
Vaidya, S. R. 1999. Metacognitive Learning Strategies for Students with Learning Disabilities. Education, 120 (1), 186-191.

Wakefiel, J.F. 1992. Creative Thinking : Problem Solving Skill and The Arts Orientation. New Jersey: Ablex Publishing Coorporation.

Woolfolk, A. 2008. Educational Psychology Active earning Edition $10^{\text {th }}$ ed. Pearson Education, Inc.

Yuan, H., et. al. 2009. Improvement of nursing students' critical thinking skills through problem-based learning in the People's Republic of China: A quasiexperimental study. Education Journal [VersiTronik]. John Wiley \& Sons,Inc.

Yustina, Salwa, dkk. 2015. Penerapan Metode Pembelajaran Problem Solving Terhadap Kemampuan Berpikir Kritis Siswa Pada Materi Koloid Kelas Xi Ipa Sma Negeri 4 Banjarmasin. Quantum, Jurnal Inovasi Pendidikan Sains, Vol.6, No.2, Oktober 2015, hlm. 108-117.

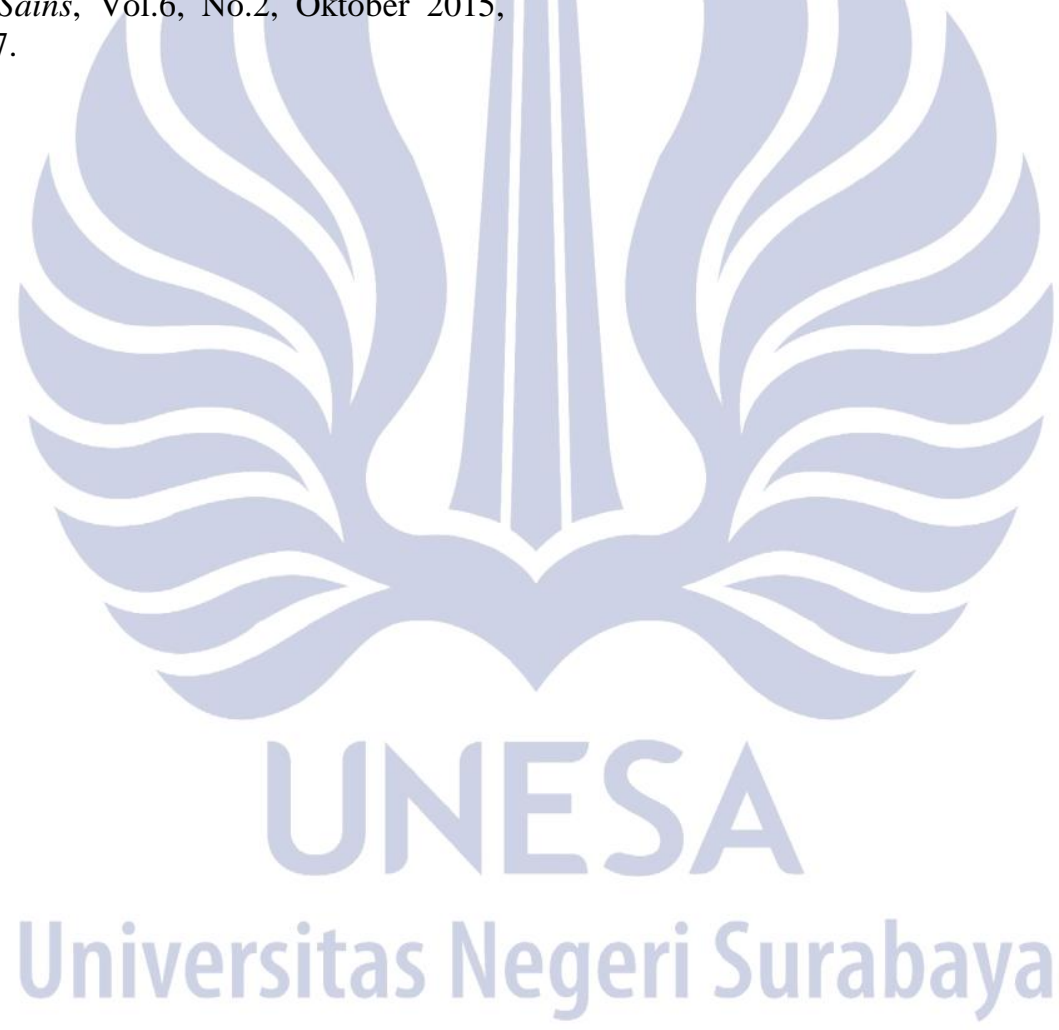

